育種学研究 $2: 215 \sim 220(2000)$

特集 記事

\title{
植物におけるプロテオーム解析と育種
}

平野 久

（横浜市立大学木原生物学研究所／大学院総合理学研究科，横浜市戸塚区舞岡町 641-12， ₹ 244-0813）

\section{Proteome Anlaysis and Breeding in Plants}

Hisashi Hirano

(Yokohama City University, Kihara Institute for Biological Research/Graduate School of Integrated Science, Maioka 641-12, Totsuka, Yokohama 244-0813, Japan)

\section{キーワード：植物, タンパク質, プロテオーム, ゲノム, ポストゲノム研究，育種}

\section{1 プロテオームとはなにか}

機能的に調和のとれた生活を営むのに必要な最小限の 遺伝子(染色体)ひとそろいを「ゲノム」と呼んでいるが, 1995 年に M. R. Wilkins は, このゲノムの遺伝子が産生 する多種類のタンパク質ひとそろいを「プロテオーム」と 呼ぶことを提唱した(Wasinger 1995).

ゲノム解析の進展により，1990年代半ばから多くの 生物でゲノムの全塩基配列が決定され, 遺伝子構造や遺 伝子発現に関する理解が深まった. しかし，同時にゲノ 厶解析で決定された塩基配列から，データベースを利用 した相同タンパク質の検索によって機能が推定できる夕 ンパク質の割合は全翻訳産物の $30 \sim 50 \%$ 程度に過ぎな いこともわかってきた。 そのためこれからはポストゲノ ム研究としてタンパク質の特性を分析し, タンパク質と 遺伝子の対応を明らかにした後, ゲノム情報を利用しな がらすべてのタンパク質, すなわちプロテオームの機能 を解明する研究を進める必要があると考えられるように なった.これに伴い「プロテオミクス」(プロテオーム科 学) と呼ばれるプロテオームに係わる新しい学問領域も 生まれた。

プロテオーム研究は, 最近発達の著しい質量分析装置 などを駆使して，ゲノム解析に相当するようなハイス ループットな (処理能力の高い) 分析によって多数のタン パク質の機能を明らかにすることを目標としている。こ の点で従来のタンパク質研究と大きく異なっている.

\section{2 トランスクリプトームとプロテオーム}

プロテオームに倣い, 全転写産物, すなわち mRNA の総体をトランスクリプトームと呼ぶようになった。ト

2000 年 9 月 19 日受領
ランスクリプトームを解析すれば，それぞれの転写産物 の発現量をハイスループットで明らかにすることができ る.しかし，この解析によって実際に機能しているタン パク質の実体を掴むのはむずかしい.タンパク質は，種 類により，また，存在する条件によって寿命が異なる. 寿命の長いタンパク質は多量に存在する必要があっても 多量に翻訳される必要はない。そのため転写産物量と翻 訳産物の存在量との間の相関はかなり低い (Anderson and Seilhamer 1997). 従って, 機能しているタンパク質の存 在量を転写産物量から正確に推定することはできない. 一方，転写産物の分析からではタンパク質の翻訳中，翻 訳後の修飾や立体構造，タンパク質相互作用などに関す る情報を得ることもできない。すべてのタンパク質は翻 訳中あるいは翻訳後に様々な修飾を受け, 特有の立体構 造をとって成熟タンパク質になる。そして，相互に作用 してはじめて機能を発揮する。従って，タンパク質の機 能を明らかにしようとする場合には，必ず機能している タンパク質そのものを分析し, 翻訳中, 翻訳後の修飾や 立体構造，相互作用などに関する情報を集めることが必 要である．それもこれからはゲノム解析に対応するよう な大規模でハイスループットなタンパク質の解析が必要 になってくる.

\section{3 育種におけるプロテオーム解析の役割}

プロテオーム解析によってゲノム DNAとそれらが コードする多くのタンパク質の対応が明らかになり, 遺 伝子とその翻訳産物の機能を効率的に解析できるように なる意義は大きい. この解析によって植物の増殖分化, 成長などに係わる新規なタンパク質が多数発見されると 期待される。すでに述べたようにこれまでに機能が明ら かにされているタンパク質は30〜50\%であるから, 現 在, タンパク質の多くは, 機能が明らかにされていない ことになる.これらの中には, 予測しなかったような機 能を持ったタンパク質も少なくないと考えられる.プロ テオーム解析によって, こうしたタンパク質の機能発現 様式について理解を深めることができれば, タンパク質 
の機能発現を遺伝的に改良することによって生産性の高 い品種を育成できる可能性がある。また，プロテオーム 解析では, 罹病や農薬, 環境などのストレスによる夕ン パク質の発現の変化を捉えることができるので，病気や ストレスに耐性を持った品種を育成する道が開かれる可 能性がある。

\section{4 プロテオーム解析の方法}

プロテオーム解析は，多種類のタンパク質を分離精製 することから始まる。タンパク質の分離精製には簡便迅 速で分離能が高い二次元電気泳動 (2-DE) が用いられる ことが多い．2-DEで分離されたタンパク質それぞれに ついて質量分析によりペプチドマップ(ペプチドマスフ インガープリントと呼ばれる)を作製したり，質量分析 装置 (MS) や気相シークエンサーにより部分アミノ酸配 列を決定する。そして，これらのデー夕を基にゲノム解 析で作製されたデータベースを検索し，タンパク質と遺 伝子の対応関係を明らかにする。

遺伝子の塩基配列からタンパク質の完全なアミノ酸配 列が推定できるので，これを用いてタンパク質配列デー タベースを検索すれば，すでに機能が明らかにされてい るタンパク質であるかどうかがわかる．また，既知の機 能をもったタンパク質と配列に類似性がある場合には夕 ンパク質の機能を推定することができる.

相同性検索によってタンパク質機能がわからない場合 にはタンパク質の各種特性を分析し，タンパク質機能の 解明を目指すことになる. タンパク質の機能を明らかに するためには, タンパク質の翻訳後の修飾, 立体構造, 発現量, 発現時期, 局在性, タンパク質相互作用, 会合, 酵素活性，生理活性などを分析する必要がある。プロテ オーム解析ではこれらの分析の結果とゲノム解析におけ る遺伝子分析の結果に基づいてタンパク質の機能を明ら かにしていく．それも 1,2 種類のタンパク質の機能の 解明を目指すのではなく，ハイスループットな分析によ って, 多数の, できればすべてのタンパク質の機能を解 明することを目標としている。

プロテオーム解析によって得られる2-DEパターンや それぞれのタンパク質の配列や構造に関する情報, 2-DEで分離されたタンパク質をコードする遺伝子の情 報，タンパク質の機能に関する情報については，データ ベース化し, 多くの研究者が利用できるようにすること が重要である。

\section{5 植物プロテオーム解析の現状}

\section{1）プロテオームの動態解析}

同じ植物種の同一個体であっても生育段階や組織器官 により発現するタンパク質の種類は異なってくる.さら に，環境によっても発現は異なる．プロテオームは極め
て動的である。これはゲノムDNAの存在が同じ個体で あれば変動しない静的なものであるのと対照的である.

2-DEを用いてタンパク質の動態を解析する研究は, ゲノム解析が始まる前から盛んに行われてきた(Thiellement et al. 1999). 特定の環境下で生育する植物の特定の 生育段階の組織器官のタンパク質が2-DEで分離され, そのパターンの種間, 品種間, 系統間差異が解析されて いる。また，生育段階や組織器官に特異的に出現あるい は消失したり (Masson and Rossignol 1995)，ホルモン処理 により変動するタンパク質も2-DEで分析された (Santoni et al. 1997). 一方，半矮性のような表現型をもつ準同質 遺伝子系統 (Hirano et al. 1991) や突然变異体 (Damerval and Le Guilloux 1998)に出現あるいは消失するタンパク 質が検出されている (Santoni et al. 1997). こうしたタン パク質の解析は，植物の成長や分化を制御するタンパク 質を同定する上で重要である。

植物においても病気やストレスで出現あるいは消失す るタンパク質を2-DEで解析した報告は多い (Ramani and Apte 1997, Rey et al. 1998, Riccardi et al. 1998). この種 のタンパク質の解析は, 耐病性や耐塩性などのストレス 耐性機構においてどのようなタンパク質が係わっている かを解明するために欠かせない。また，植物がもつアレ ルゲンタンパク質 (Weiss et al. 1997), ビールの麦芽品質 関連タンパク質 (Görg et al. 1992), 製パン性関連タンパ ク質 (Lafiandra and Kasarda 1985)などが2-DEで同定され ているが，これらは植物タンパク質の食品としての機能 を明らかにする上で重要性が高い. タンパク質の動態に 関するこれまでの研究の大半はポストゲノム研究である プロテオーム研究として進められてきたものではない が，タンパク質の機能の解明につながる研究であると考 えられるのでプロテオーム研究の一環と捉えるべきであ ろう。

最近, Gygi et al.(1999)や Oda et al.(1999)によって MS を用いて異なる状態の細胞のタンパク質量の違いを定量 的に測定する方法が報告された。いずれの方法も異なる 状態の細胞のタンパク質を安定同位体で標識し, MSに よる分析で得られるぺプチドマスフィンガープリントを 比較することによってタンパク質含量の違いを解明しよ うとするものである。これらの方法は, タンパク質の絶 対量を正確にとらえることはむずかしいが，異なる状態 にある組織細胞のタンパク質含量の相対的な違いを，そ れがわずかな違いであっても，検出できる，どちらの方 法でも同じタンパク質であれば同位体標識後も物理化学 的な性質にほとんど差がないので，イオン化の効率に差 異は出ない。従って, MSで精度の高い定量的な分析を 行うことができる。このような手法を用いて植物でも夕 ンパク質の動態を解析する研究が行われようとしてい る。 
+
$-\mathbf{A}$

$-A$

$+$

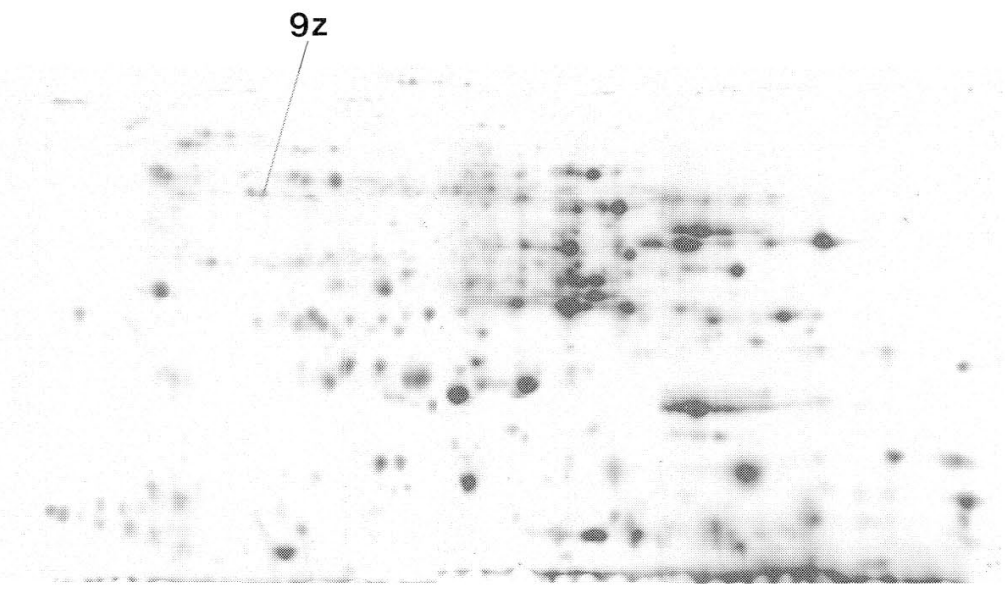

B
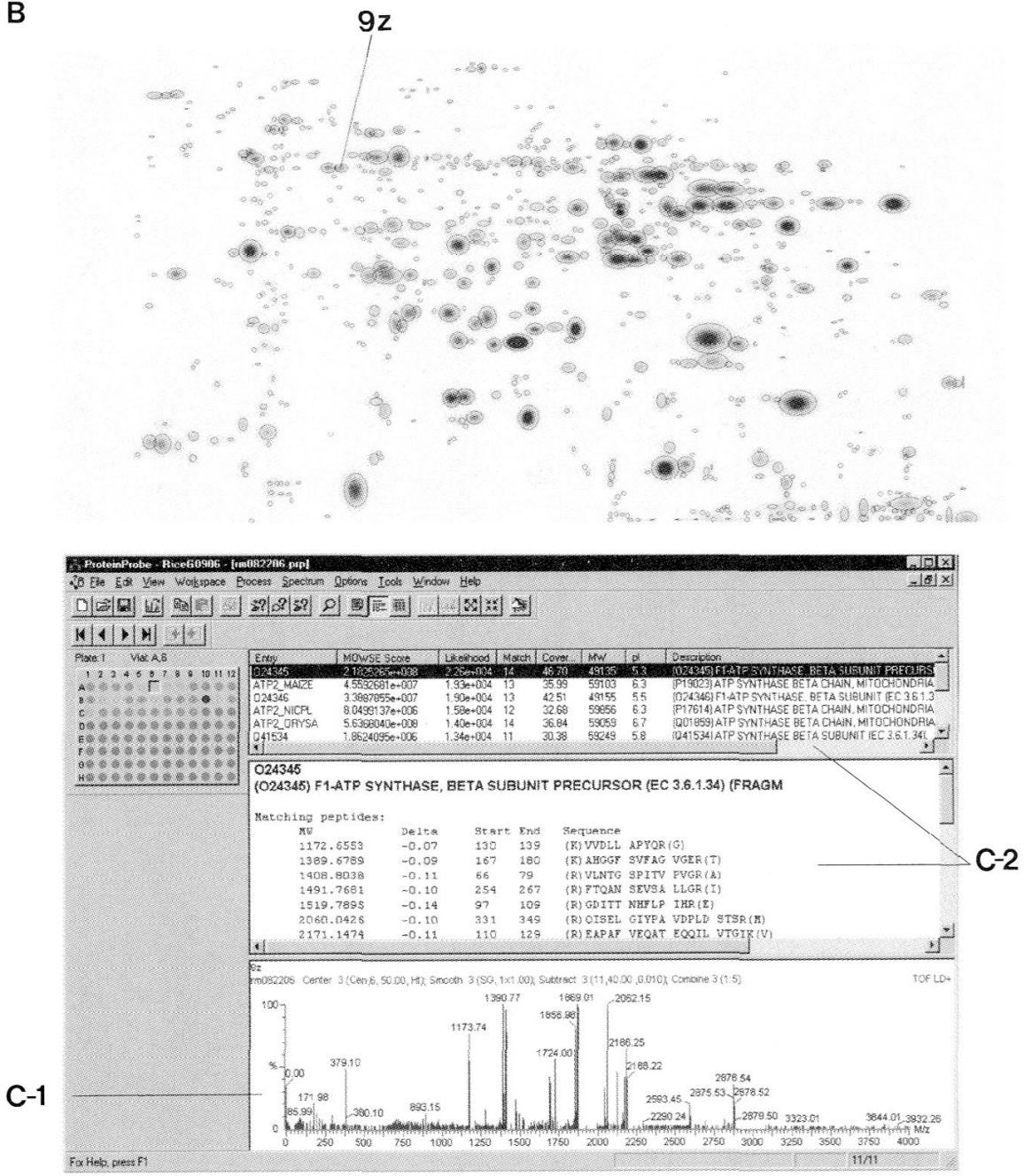

図 1.MALDI-TOF MS によるイネ種子胚芽タンパク質の同定(福田・禹・山岸・清水・高岡・平野, 未発表) イネ(品種 日本晴)種子肧芽タンパク質を2-DEで分離した(図 1A).2-DEパターンは, PDQuest 画像解析ソ フトウエア（日本バイオラッドラボラトリーズ社）を用いて解析し，スポットの位置を確定した(図1B)㖟， 各スポットの等電点, 分子量, 濃度を推定した. 2-DEゲルからタンパク質スポット (9z)を切り取り, トリ プシンでタンパク質のゲル内消化を行った(福田ら 2000)。この処理によりタンパク質はリシンとアルギニン のC末端で特異的に切断される．得られたペプチド混合物をMALDI-TOF MSの試料ターゲットに添加し， 質量分析を行い,ペプチドマスフィンガープリントを作成した(図 1C-1).これと同じペプチドマスフィンガー プリント組成を持つタンパク質をデータベースで倹索した結果，このスポットはF1-ATP合成酵素のスポッ トであることがわかった(図1C-2). 


\section{2）タンパク質・遺伝子の同定}

1987 年に電気泳動で分離されたタンパク質をPVDF 膜のような膜フィルターにブロットし, 気相シークエン サーで部分アミノ酸配列を分析する方法が開発された (Matsudaira 1987)が，この方法を応用して 1980 年代後 半から植物に関しても2-DEで分離された多数のタンパ ク質の部分アミノ酸配列が分析され, タンパク質を同定 する研究が行われた(Hirano 1989). その後, イネ(Hirano 1997, Komatsu et al. 1994, Tsugita et al. 1994, Zhong et al. 1997), トウモロコシ(Riccardi et al. 1998), コムギ (Gomez et al. 1991)，オオムギ(Flengsrud 1993), シロイ ヌナズナ(Kamo et al. 1995, Santoni et al. 1998), タバコ (Rouquie et al. 1997) など多くの植物で類似の研究が行わ れた(梶原 2000).

最近, マトリックスアシステッドレーザーデソープシ ヨンイオン化飛行時間型質量分析装置 (MALDI-TOF $\mathrm{MS})$ のような MS が発達し, 2-DEで分離されたタンパ ク質をゲル中でトリプシンのようなプロテアーゼにより 消化して生じるペプチドを MSによって高感度, 高精度 かつハイスループットで分析できるようになった．この 際得られる質量スペクトル(ペプチドマスフィンガープ リント)をデータベース中のタンパク質の理論的なペプ チドマスフィンガープリントと比較することによりタン パク質の同定 (図 1)が植物でも行われている。一方, MALDI-TOF MS とポストソースディケイ法(イオン源で イオン化された後，イオン自体の内部エネルギーにより タンパク質あるいはペプチドの断片化が起こる．この断 片を分離検出する方法)を組み合わせた MS やエレクト ロスプレイイオン化四重極TOF MSのような MS/MSを 用いることにより，ごく微量のペプチドのアミノ酸配列 が決定できるようになった。しかし，植物に関しては， MS を用いて2-DEで分離したタンパク質の部分配列を ハイスループットで決定し，タンパク質を同定したとい う報告はない.

プロテオーム解析では，2-DEで分離されたタンパク 質とゲノム解析で単離された遺伝子との対応関係を明ら かにする必要がある。プロテオーム解析はゲノム解析の 成果を最大限活用するために行われるものであるから， タンパク質と遺伝子の対応を明らかにすることは極めて 重要である，遺伝子の同定には，通常，MSにより得ら れたペプチドマスフィンガープリントや MS や気相シー クエンサーにより決定された部分アミノ酸配列が用いら れる。

イネでは，1996年時点でゲノムプロジェクトにおい て約 2 万の Expressed Sequence Tag (EST)の塩基配列が決 定された。これらのESTの重複度は約 $50 \%$ であと推 定されている.イネには $2 \sim 4$ 万の遺伝子が存在すると みられるので, クローニングされた ESTは全遺伝子の 25〜50\%と推定される. 2-DEで分離された 1800 以上の 胚芽, 胚乳, 葉および根のタンパク質のうち, 126 のア
ミノ酸配列が気相シークエンサーにより決定され，アミ ノ酸配列に基づいて約 $30 \%$ のタンパク質をコードする ESTが検索された(Hirano 1997). EST と対応がついた夕 ンパク質の比率は約 $30 \%$ で，上記のクローニングされ たESTの比率 $(25 \sim 50 \%)$ の範囲に入っていた. 最近は, ESTが3万を越えたが，アミノ酸配列からタンパク質を 検索したところ，60\%以上のタンパク質をコードする DNAを同定できることがわかった。これは理論的な值と 概ね一致する。1999年からは, 著者の研究室でMALDITOF MSを用いたペプチドマスフィンガープリンティン グによりイネのタンパク質や遺伝子をハイスループット で同定する研究が始まった。

シロイヌナズナでは，葉の原形質膜画分に含まれる 700 のタンパク質が2-DEによって分離された (Santoni et al. 1998). このうち, 約 550 が原形質膜に存在するもの であると推定された．ゲル中のタンパク質のトリプシン 分解で得られたペプチドが高速液体クロマトグラフィー で精製され，エドマン分解によりアミノ酸配列が分析さ れた。その結果，82 スポットの部分アミノ酸配列が明 らかになった.このうち機能が明らかなタンパク質は約 $65 \%$ あ゙あた。また，機能はわからないがESTが同定 できたものは約 20\%あった(Santoni et al. 1998).この場 合は，ゲノム解析で得られた 3 万 6 千のESTからタンパ ク質に対応するESTの同定が行われた。

上記イネおよびシロイヌナズナの研究によって, 2-DEで分離されたタンパク質の部分アミノ酸配列情報 を利用してゲノム解析で得られたDNAライブラリーの 遺伝子とタンパク質の対応を明らかにできることが確か められた，今後，ESTライブラリーが拡充されたり，ゲ ノムの完全な配列が決定されると予測されるが，その段 階ではタンパク質と遺伝子を $100 \%$ 対応づけることがで きると考えられる。

\section{3） プロテオームの機能解析}

機能が明らかにされていないタンパク質の機能を, 翻 訳中や翻訳後の修飾, タンパク質の相互作用, 立体構造 などをハイスループットで解析することにより明らかに していくことがプロテオーム解析の重要な目的である. 次に示す実験例は，2-DEで分離された植物タンパク質 の機能を著者らがプロテオーム解析の方法を用いて分析 した例である。

ダイズの種子で発現するタンパク質を2-DEで分析し た.その結果, $27 \mathrm{kD}$ のサブユニットと $16 \mathrm{kD}$ のサ ブユニットからなる塩基性タンパク質 (LBP)が検出され た(平野 1998). 研究開始の時点で, このタンパク質の 構造と機能は知られていなかった. LBP は, ダイズの他, リョクトウ，インゲンマメ，アズキなどのマメ科植物や ニンジンなどでも見いだされた，LBPの構造的特徴を調 べたところ，LBPには動物のインスリン受容体と構造上 の類似性があることがわかった。 また，LBPは，プロテ 
インキナーゼ活性をもち，インスリン受容体と同じよう に原形質膜 (一部細胞壁)に局在することが明らかになっ た.そこでLBPをリガンドとしてアフィニティークロ マトグラフィーにより LBPに結合する活性をもつタン パク質を精製したところ, 分子量 3,900 のペプチドを単 離することができた.レグインスリンと命名したこのペ プチドは 37 残基からなり，インスリンとアミノ酸配列 に相同性はないが，インスリン同様，6残基のシステイ ンをもち，これらのすべてがジスルフィド結合に係わっ ていた。レグインスリンは細胞壁近傍に局在しており, LBP に結合するとそのプロテインキナーゼ活性を克進し た.この際，レグインスリンのジスルフィド結合を切断 するとその効果は見られなくなった。核磁気共鳴スペク トルにより解析したレグインスリンの三次構造にはイン スリンの構造と一部類似した点があった。また，レグイ ンスリンをニンジンカルス培養培地に添加すると, 植物 体分化能や胚形成能に影響が現われた。ささらに，ニンジ ン培養細胞の分裂の促進効果が認められた。 また,レグ インスリン遺伝子を導入した形質転換体ではカルスの初 期生育にレグインスリンの効果が見られた。これらの結 果から，レグインスリンにはレグインスリン受容体と考 えられるLBPのリン酸化を介して成長や分化, 細胞分 裂の制御に係わっていると推察された. 動物では, すで に多くのペプチドホルモンの存在が知られている.これ らの中には, 受容体に結合し, そのプロテインキナーゼ 活性を立進することによりホルモン情報の伝達を行い, 動物の成長や分化を制御しているものがある. しかし, 植物では，これまでこのようなホルモンやその情報伝達 系の存在は明らかでなかった.

上記の研究例では，2-DEで分離されたタンパク質を プロテオーム解析の手法を使って分析することにより, ホルモンと類似した機能をもつペプチドとそれによる情 報伝達系の存在を示唆することができた.プロテオーム 解析ではこの種の研究を多数のタンパク質を対象にして ハイスループットで行う必要がある。しかし, 植物では まだタンパク質の機能を網羅的にハイスループットで解 析する研究は行われていないのが実状である.
4）プロテォームのスモールワールド, 複合体

細胞内のすべてのタンパク質について機能を解明する ことは現時点では容易なことではないが, タンパク質複 合体中のタンパク質の機能を解明することは細胞内のす べてのタンパク質の機能を解明することほど困難ではな い. 機能的に何らかの関係をもつ複合体中のタンパク質 を次々と調べていけば，ゲノムによりコードされた多く のタンパク質の機能をより効率的に解析できる可能性が ある.このような観点から, 著者らは, 31 種類のサブ ユニットからなる巨大タンパク質複合体であるプロテア ソームに的を絞り, プロテアソームサブユニットのすべ ての翻訳中および翻訳後の修飾と機能の関係の解明を目 指す研究に始めた。 これまでにすべてのサブユニットの $\mathrm{N}$ 末端アセチル化やリン酸化といった翻訳後の修飾を網 羅的に解析し, それらの修飾と機能との関係を示唆する 結果を得た (Ito et al. 2000, 岩船ら 2000, Kimura et al. 2000, Sassa et al. 2000). 今後, プロテオーム解析によ って得られる情報を基に，すべてのサブユニットの機能 をより明確なものにすることができると考えられる.

\section{5）植物プロテオームのデータベース化}

いくつかの植物では，プロテオーム解析によって得ら れる2-DEパターンや分離されたタンパク質の配列や構 造, 各タンパク質をコードする遺伝子, タンパク質の機 能などに関する情報がデータベース化されている．シロ イヌナズナ (http://sphinx.rug.ac.be:8080/ppmdb/index.html) やトウモロコシ (http://moulon.inra.fr/imgd) データベース が比較的充実している．例えば，シロイヌナズナのデー タベースにアクセスすると，まず2-DEパターンを見る ことができる.ゲル上のスポットをクリックすると, 夕 ンパク質の等電点, 分子量, MS データ, アミノ酸配列, 疎水性, 細胞内局在性, 動態, 他のデータベースとのリ ンク，発表論文などに関する情報を入手することができ る.また，分析に用いられた方法も詳しく記載されてい る.このようなデータベースを今後充実させていくこと が重要である.なお，プロテオームデータベースは， DNA やタンパク質配列データベースと異なり，新しい データを外部から登録できるシステムがない。この点は

表 1.プロテオーム解析に用いられる主な分析機器

\begin{tabular}{|c|c|}
\hline タンパク質の分離精製 & 云次元電気泳動装置, ブロッティング装置, 蛍光イメージアナラ \\
\hline 二次元電気泳動画像解析 · データベース化 & 画像解析装置, ソフトゥエア \\
\hline タンパク質・遺伝子の同定 & $\begin{array}{l}\text { 質量分析装置(MALDI-TOF MS およびESI Q-TOF MS)，気相シー } \\
\text { (Mササ }\end{array}$ \\
\hline タンパク質の翻訳後修飾の解析 & 質量分析装置 (ESI Q-TOF MS) \\
\hline タンパク質の立体構造解析 & 核磁気共鳴装置, X線解析装置 \\
\hline タンパク質相互作用の解析 & $\begin{array}{l}\text { 表面プラズモン共鳴測定装置, 質量分析装置 (MALDI-TOF MS お } \\
\text { よ }\end{array}$ \\
\hline タンパク質の動態解析 & $\begin{array}{l}\text { 二次元電気泳動装置, 質量分析装置(MALDI-TOF MS およびESI } \\
\text { Q-TOF }\end{array}$ \\
\hline
\end{tabular}


大きな課題になっている.

\section{6 植物プロテオーム解析の課題}

すでに述べたように，プロテオーム解析ではあらゆる 組織であらゆる時期に発現するタンパク質の解析が必要 であるから，プロテオーム研究はゲノムプロジェクトよ りはるかに時間と労力のかかる研究になると推測され る.この研究を迅速に推進するためには，大規模なプロ テオーム解析を進めるための研究組織の構築が大きな課 題になるように思われる，小さなゲノムサイズの生物の プロテオーム解析は数人の研究グループでも対応できる かも知れない. しかし，ゲノムサイズの比較的大きい植 物のプロテオーム解析を行おうとする場合には，大きな 研究組織を構築することが重要である.

一方，プロテオーム解析では，2-DE，2-DE画像解析 装置, MS, 核磁気共鳴装置, X線解析装置, プラズモ ン共鳴測定装置など多種類の分析装置を用いる必要があ る(表1). しかし, 現在の装置は, 大規模なプロテオー 厶解析に必ずしも十分なものではない．なお一層の高感 度化・高精度化，そして分析の迅速化・自動化が望まれ ている．また，得られた情報のデータベース化とその利 用技術の開発もまた不可欠である。

\section{引用文献}

Anderson, L. and J. Seilhamer (1997) Electrophoresis 18: 533-537.

Damerval, C. and M. Le Guilloux (1998) Mol. Gen. Genet. 257: 354-361.

Flengsrud R. (1993) Electrophoresis 14: 1060-1066.

福田正史・岩船裕子・ 川崎博史・平野 久 (2000) 育種学研究 2 (別 1): 89 .

Gomez, L., R. Sanchez-Monge, C. Lopez-Otin and G. Salcedo (1991) J. Cereal Sci. 14: 117-123.

Görg, A., W. Postel, M. Baumer and W. Weiss (1992) Electrophoresis 13: $192-203$.

Gygi, S. P., B. Rist, S. A. Gerber, F. Turecek, M. H. Gelb and R. Aebersold (1999) Nature Biotech. 17: 994-999.

Hirano, H. (1989) J. Protein Chem. 8: 115-130.

Hirano, H. (1997) J. Protein Chem. 16: 533-536.

平野 久(1998)蛋白質核酸酵素, 43: 27-39.

Hirano, H., S. Komatsu, A. Nakamura, F. Kikuchi, H. Kajiwara, S. Tsunasawa and F. Sakiyama (1991) Theor. Appl. Genet. 83:
153-158.

Ito, K., Y. Kimura, H. Sassa and H. Hirano (2000) Jpn. J. Electrophoresis, 44: 205-210.

岩船裕子・鍵 紀子·川崎博史・平野 久 (2000) 生化学, 72 : 771.

梶原英之 (2000) 植物のプロテオーム解析. 実験医学別冊プロテ オーム解析法, 磯辺俊明. 高橋信弘編, 237-240, 羊土社, 東京.

Kamo, M., T. Kawakami, M. Miyatake and A. Tsugita (1995) Electrophoresis 16: 423-430.

Kimura, Y., M. Takaoka, S. Tanaka, H. Sassa, K. Tanaka, B. Polevoda, F. Sherman and H. Hirano (2000) J. Biol. Chem. 275: 46354639.

Komatsu S., H. Kajiwara and H. Hirano (1994) Theor. Appl. Genet. 86: 935-942.

Lafiandra, D. and D. D. Kasarda (1985) Cereal Chem. 62: 314-319.

Masson, F. and M. Rossignol (1995) Plant J. 8: 77-85.

Matsudaira P. (1987) J. Biol. Chem. 262: 10035-10038.

Oda, Y., K. Huang, F. R. Cross, D. Cowburn and B. T. Chait (1999) Proc. Natl. Acad. Sci. USA 96: 6591-6596.

Ramani, S. and S. K. Apte (1997) Biochem. Biophys. Res. Commun. 233: 663-667.

Rey, P., G. Pruvot, N. Becuwe, F. Eymery, D. Rumeau and G. Peltier (1998) Plant J. 13: 97-107.

Riccardi, F., P. Gazeau, D. de Vienne and M. Zivy (1998) Plant Physiol. 117: 1253-1263.

Rouquié, D., J.-B. Peltier, M. Marquis-Mansion, C. Tounaire, P. Doumas and M. Rossignol (1997) Electrophoresis 18: 654-660.

Santoni, V., D. Rouquié, P. Doumas, M. Mansion, M. Boutry, H. Degand, P. Dupree, L. Packman, J. Sherrier, T. Prime, G. Bauw, E. Posada, P. Rouzé, P. Dehais, I. Sahnoun, I. Barlier and M. Rossignol (1998) Plant J. 16: 633-641.

Santoni, V., M. Delarue, M. Caboche and C. Bellini (1997) Planta 202: 62-69.

Sassa, H., S. Oguchi, T. Inoue and H. Hirano (2000) Gene 250: 61-66. Thiellement, H., N. Bahrman, C. Damerval, C. Plomion, M. Rossignol, V. Santoni, D. de Vienne and M. Zivy (1999) Electrophoresis 20: 2013-2026.

Tsugita, A., T. Kawakami, Y. Uchiyama, M. Kamo, N. Miyatake and Y. Nozu (1994) Electrophoresis 15: 708-720.

Weiss, W., G. Huber, K.-H. Engel, A. Pethran, M. Dunn, A. A. Gooley and A. Görg (1997) Electrophoresis 18: 826-833.

Wasinger, V. C., S. J. Cordwell, A. Cerpa-Poljak, J. X. Yan, A. A. Gooley, M. R. Wilkins, M. W. Duncan, R. Harris, K. L. Williams and I. Humphery-Smith (1995) Electrophoresis 16: 1090-1094.

Zhong, B.-X., S. Komatsu, H. Karibe, H. Ichimura, Y. Nagamura, T. Sasaki and H. Hirano (1997) Breed. Sci. 47: 245-251. 